\title{
Review of Black Ranching Frontiers: African Cattle Herders of the Atlantic World, 1500-1900 by Andrew Sluyter
}

Nathan F Sayre

\author{
Book details \\ Andrew Sluyter \\ Black Ranching Frontiers: African Cattle Herders of the Atlantic World, 1500-1900. \\ New Haven: Yale University Press; 2012. \\ 320 pages, maps, figures, photographs, index, ISBN 978-0-300-17992-7 (cloth) \$45.00; elSBN 9780300183238 (ebook) \\ prices vary.
}

Keywords: Pastoralism; Ranching; New World; Slavery; Black Atlantic; Herding ecology

Judith Carney's (2001) path-breaking book, Black Rice: The African Origins of Rice Cultivation in the Americas, drew long-overdue attention to the active role of African slaves in the agricultural settlement of the New World. Carney showed that slaves were not merely the labour force that executed the designs of white overlords, but agents whose knowledge and creativity were essential to successful settlement, both enabling and resisting the larger production systems of the plantation South. Andrew Sluyter's Black Ranching Frontiers avowedly emulates Carney in applying her methods and insights to the related but distinct case of New World cattle husbandry, specifically the open range variant famously associated with ranching.

That African Americans and other ethnic minorities were present and significant in the development of ranching in the US - notwithstanding its mythic association with white Anglophone males - was conclusively established by Terry Jordan (1993) in North American Cattle-Ranching Frontiers, and Sluyter, who studied with Jordan at the University of Texas, shares Jordan's diffusion-and-differentiation approach to his subject. But Sluyter expands the scope of investigation to encompass South and Central America as well as North America and the Caribbean, while limiting his focus to the sixteenth

Correspondence: nsayre@berkeley.edu

Department of Geography, University of California-Berkeley, 507 McCone Hall, Berkeley, CA 94720, USA to the eighteenth centuries. He also brings a finer resolution to the analysis by looking in great detail at specific geographic sites (rather than regions) and, to the extent possible, at specific individuals rather than culturally defined 'systems' of livestock production. Finally, following Carney, Sluyter views these actors and places as constituting trans-Atlantic networks through processes of trade, knowledge production and hybridization.

Sluyter's thesis - that 'blacks played a creative role in the establishment of cattle ranching in at least a few American places' (p. 220) - is persuasively supported by empirical evidence from a remarkable array of sources throughout the western hemisphere, including West Africa, the United Kingdom and the Mediterranean, as well as the New World. He has painstakingly combed through census data, property records, ships' manifests, patent filings, maps and slave trade inventories from British, French, Spanish and Portuguese colonial and post-colonial sources. And this is not only an archival project: Sluyter also conducted field research at his far-flung sites - from the Pampas to Louisiana and from Barbuda to the Gulf coast of Mexico to find artefacts and landscape traces of the activities he describes. In its detail and diversity of evidence, Black Ranching Frontiers stands as a remarkable scholarly achievement.

Despite - and in a sense because of - this archival abundance, Sluyter must contend throughout the book with tricky epistemological and evidentiary issues. If

\section{实}

(C) 2014 Sayre; licensee Springer. This is an Open Access article distributed under the terms of the Creative Commons Attribution License (http://creativecommons.org/licenses/by/4.0), which permits unrestricted use, distribution, and reproduction in any medium, provided the original work is properly credited. 
scholars have long overlooked the role of Africandescended agents in New World cattle husbandry, it is in large measure due to the biases and blind spots of those who produced the archives on which scholars have relied. Whether enslaved or not, blacks in the Americas from the sixteenth to the eighteenth centuries (and beyond) were politically, economically, socially and educationally marginalized. They were unlikely to leave behind detailed written records of their activities, and both colonial and post-colonial elites were unlikely to credit them with agency or creativity even when such credit was due. To reconstruct their roles, then, Sluyter has to read the archives against the grain, triangulating between multiple sources and identifying inconsistent or implausible stories that erase and conceal the very claims he seeks to make. ' $[\mathrm{N}]$ o known documents conclusively relate black slaves to livestock herding in Andalusia' (p. 41), for example, but once one considers how the Spanish laws governing livestock husbandry were racially differentiated, how they were applied in New World settings and the practices that subsequently emerged (such as the use of the lasso from horseback), it becomes plausible to conclude that 'the sheer number of enslaved and free blacks who lived there [in Veracruz] during the colonial period suggests that they may well have played roles in the establishment of cattle ranching' (p. 50).

Positive proof of his claims is often impossible to find, and Sluyter chooses his words carefully to avoid overstating his case, routinely employing phrases like 'reasonably certain' (p. 146), 'at least allow for the possibility' (p. 148), 'potentially played a creative role' (p. 149) and 'seems most probable' (p. 168). Generally, he is forced to rely on a preponderance-of-evidence standard: 'more evidence exists to suggest that actors of black, native, and mixed origins-especially griffes-rather than whites participated in Atlantic networks that brought knowledge of cattle herding to the Attakapas [in Louisiana]' (p. 96). But the evidence can be rather slim: 'at least some of them [non-whites] may have had prior knowledge of openrange cattle herding, whereas 'none of the [white] ranchers had any such experience' (p. 94).

Such qualifications may disquiet some scholars, but they are understandably necessary given the evidence available, and along the way, Sluyter presents fascinating stories and little-known details about livestock husbandry, the production and trade of meat and other cattle-derived products, and the networks that connected livestock to people, places and other economic sectors in the New World and across the Atlantic. The case of tasajo - a saltcured beef produced in the Pampas and shipped to the Caribbean as cheap protein for slave labourers on sugar plantations - featured in chapter 6, is a great example of the fruits of Sluyter's original research. But tasajo also illustrates a tension between networks and processes, on the one hand, and the diffusion of cultural artefacts and techniques, on the other, as the methodological and theoretical touchstones of Sluyter's project. In contrast to the other chapters, Sluyter is relatively unconcerned about whether blacks, whites, natives or mixed-race individuals brought (or created) the knowledge to produce tasajo in the Pampas - and rightly so, because those details seem almost immaterial compared to what tasajo reveals about the political economy of the New World at the time. Here, Sluyter's approach resembles that of Sidney Mintz (1985) in Sweetness and Power more than that of Jordan.

To be sure, identifying cultural and technical antecedents for practices found in specific New World sites is a valuable method to trace networks and the movements that constitute those networks. But transposing specific livestock husbandry practices onto ethnic classifications in order to link them to other kinds of data (e.g. census records enumerated by race) has its limits as a means of explanation. Apart from the risk of racial essentialism, the diffusion model begs questions about innovation and change. Sluyter runs into these limits in the case of Barbuda, one of the Leeward Islands in the eastern Caribbean, where trap corrals built around wells allowed black herders to capture feral cattle for white owners. It is one of the best chapters in the book, and after detailed analysis of the available evidence, Sluyter concludes: 'In terms of the characteristics of the Barbudan herding ecology, then, its origins seem diverse and partially endogenous' (p. 134). He goes on: 'A reasonable interpretation of the Barbudan herding ecology suggests that it was subject to diverse influences and local innovation because of the lack of antecedent knowledge among those involved in its emergence' (p. 135). And finally, 'The networks of commerce and migration simply remain too poorly known to derive a more definitive conclusion about broader Barbudan relationships' (p. 138).

These conclusions are entirely reasonable. But if lack of direct evidence here indicates likely endogenous innovation, should not such innovation also be considered a possibility in other cases, where the evidence is likewise indirect? More importantly, even if a practice was imported from elsewhere, its origins in the antecedent location are not really explained by the culture, race or ethnicity of the people there. At some point further back in time, someone had to actively and creatively come up with a new practice, and that too was probably a 'hybrid' moment with diverse contributing processes. Where complex techniques or tools are involved - as with the water hoists found in the Pampas, which Sluyter traces to Senegambian origins - a diffusionist interpretation seems more plausible. But with simpler and more generic practices, such as the use of live fences (shrubs or 
trees planted and pruned to serve as barriers or enclosures), endogenous innovation may well suffice.

Sluyter has unquestionably made a major contribution to our knowledge of New World livestock husbandry's early roots and movements, and the above criticisms are minor relative to the value of the underlying research he has produced. To remedy the blind spots of past scholarship - and the biases behind them - does necessarily entail employing the racialized categories through which this history - and the history of the New World more generally - was produced. But one is tempted to conclude that scholars (and others) ought by now to presume that blacks played active roles in that history, shifting the burden of proof to the other side and opening up other frameworks for historical and geographical analysis.

\section{Competing interests}

The author declares that he has no competing interests.

\section{Author information}

Nathan Sayre is Associate Professor and Chair of Department of Geography, University of California-Berkeley, USA.

Received: 4 June 2014 Accepted: 6 June 2014

Published online: 26 June 2014

\section{References}

Carney, JA. 2001. Black rice: The African origins of rice cultivation in the Americas. Cambridge: Harvard University Press.

Jordan, TG. 1993. North American cattle-ranching frontiers: Origins, diffusion, and differentiation. Albuquerque: University of New Mexico Press.

Mintz, SM. 1985. Sweetness and power: The place of sugar in modern history. New York: Viking.

doi:10.1186/s13570-014-0008-3

Cite this article as: Sayre: Review of Black Ranching Frontiers: African Cattle Herders of the Atlantic World, 1500-1900 by Andrew Sluyter.

Pastoralism: Research, Policy and Practice 2014 4:8.

\section{Submit your manuscript to a SpringerOpen ${ }^{\odot}$ journal and benefit from:}

- Convenient online submission

$\checkmark$ Rigorous peer review

- Immediate publication on acceptance

- Open access: articles freely available online

- High visibility within the field

- Retaining the copyright to your article 